FITRAH Jurnal Kajian Ilmu-ilmu Keislaman

Vol. 04 No. 1 Juni 2018

e-ISSN : 2460-2345, p-ISSN: 2442-6997

Web: jurnal.iain-padangsidimpuan.ac.id/index.php/F

\title{
STRATEGI KEPALA SEKOLAH DALAM MENINGKATKAN KOMPETENSI GURU TERHADAP HASIL BELAJAR SISWA DI SMA NEGERI 1 PEUKAN BADA ACEH BESAR
}

\author{
EKA MAYASARI DAN MUHAMMAD SYARIF \\ Fakultas Agama Islam Universitas Serambi Mekkah Banda Aceh
}

\begin{abstract}
The Principal's strategy is the important factor for determining the succesfull of increasing teacher's competency. The aims of this study was to know the program, implementation, evaluation and obstacle that's faced by principal of SMA Negeri 1 Peukan Bada Aceh Besar. This research was conducted by descriptive qualitative methode. the data were collected by observation, interview adn documenation technique. The subcject of this research was a principal, vice of principal and teachers. The data was analyzed by data reduction, data display, drawing conclusion and data verification. The result shown that (1) The program of the principal for increasing teacher's competency in SMA Negeri 1 Peukan Bada Aceh Besar was prepared by team of school develpoment in the beginning of the semester or the school year which is including annual program, semester program and it has been documented well. Commonly it relates to the quality of learning that always start with lesson plans ( RPP). (2) The implementation of the program for increasing teacher's competency in SMA N 1 Peukan Banda Aceh Besar was started by presenting the instruction on the beginning of each semester. In implementing the strategy of school management, the principal/ school was applying kinship's principle, however teachers who can increase their competency, they will get reward, and the teacher who are less in their competency, they will get reproof. (3) the evaluation of principal for increasing teacher's competency was carried out at the end of each semester through the assessment of teacher's performance that's described in SKP, (4)the obstacle of principal for increasing teacher's competency was include lack of teacher's awareness in upholding discipline and low disciplines of both tecahers and the students.
\end{abstract}

Keywords : Strategy of Principal and tecaher's competency

\begin{abstract}
Abstrak
Strategi kepala sekolah merupakan faktor yang penting dalam menentukan keberhasilan peningkatan kompetensi guru. Tujuan penelitian ini untuk mengetahui program, pelaksanaan, evaluasi dan hambatan-hambatan yang dihadapi kepala sekolah SMA Negeri 1 Peukan Bada Aceh Besar. Penelitian ini menggunakan metode deskriptif dengan pendekatan kualitatif. Teknik pengumpulan data melalui observasi, wawancara, dan dokumentasi. Subjek penelitian adalah kepala sekolah, wakil kepala sekolah dan guru. Data dianalisis dengan cara: reduksi data, display data, mengambil kesimpulan dan verifikasi data. Hasil penelitian menunjukkan: (1) Program kepala sekolah dalam meningkatkan kompetensi guru pada SMA Negeri 1 Peukan Bada Aceh Besar
\end{abstract}


FITRAH Jurnal Kajian Ilmu-ilmu Keislaman

Vol. 04 No. 1 Juni 2018

disusun setiap awal semester atau awal tahun pelajaran oleh tim pengembang sekolah yang meliputi program tahunan, program semester dan sudah terdokumentasi dengan baik. Pada umumnya berkaitan dengan pembelajaran yang berkualitas yang dimulai dari RPP; (2) Pelaksanaan program dalam meningkatkan kompetensi guru pada SMA Negeri 1 Peukan Bada Aceh Besar diawali dengan menyampaikan arahan pada setiap awal semester. Dalam melaksanakan manajemen sekolah strategi kepala sekolah/sekolah menerapkan dengan prinsip kekeluargaan, namun bagi yang meningkatkan kompetensinya diberikan penghargaan dan adanya teguran bagi guru yang kurang peduli terhadap peningkatan kompetensinya; (3) Evaluasi kepala sekolah dalam meningkatkan kompetensi guru dilaksanakan pada setiap akhir semester melalui penilaian kinerja guru yang dijabarkan dalam SKP; (4) Hambatan yang dihadapi kepala sekolah antara lain kurangnya kesadaran guru dalam menegakkan kedisiplinan, dan rendahnya disiplin baik guru maupun peserta didik.

Kata Kunci: Strategi kepala sekolah dan kompetensi guru

\section{PENDAHULUAN}

Peningkatan kualitas pendidikan sebagai salah satu prinsip dari strategi pembangunan pendidikan nasional didasarkan pada visi misi sistem pendidikan yang strategis. Visi strategis sistem pendidikan haruslah merangkum beberapa hal, terutama dalam penyusunan strategi pengembangan sumber daya manusia (SDM) untuk mengidentifikasi kekuatan-kekuatan global di masa yang akan datang. Salah satu faktor penting dalam pengembangan sumber daya manusia adalah melalui pendidikan seperti pada lembaga pendidikan sekolah, yang dilaksanakan oleh kepala sekolah sebagai pemimpin baik untuk lembaga maupun terhadap pembinaan bagi guru.

Di antara pemimpin pendidikan ada bermacam-macam jenis dan tingkatannya, antara lain kepala sekolah, yang merupakan pemimpin pendidikan yang sangat penting, karena berhubungan langsung dengan pelaksanaan program dan tujuan pendidikan di sekolah. Ketercapaian tujuan pendidikan sangat tergantung pada kecakapan dan kebijakan oleh kepala sekolah sebagai pemimpin pendidikan. Hal ini dikarenakan kepala sekolah merupakan seorang pejabat profesional yang bertugas mengatur semua sumber organisasi dan bekerjasama dengan guru-guru dalam mendidik siswa untuk mencapai tujuan pendidikan di sekolah.

Wahyudi ${ }^{1}$ mengatakan bahwa: "Otonomi pengelolaan pendidikan di sekolah berkaitan dengan pendelegasian wewenang kepada kepala sekolah".

1 Wahyudi, Kepemimpinan Kepala Sekolah Dalam Organisasi Pembelajaran (Bandung: Alfabeta, 2009), hlm. 33. 
Agar wewenang yang diberikan dapat dijalankan dengan baik, maka diperlukan kepala sekolah yang kompeten dalam merencanakan dan menjalankan serta mengevaluasi program-program sekolah. Menurut Mulyono ${ }^{2}$ (2008:70) mengatakan bahwa: "Sekolah adalah organisasi yang kompleks dan unik, sehingga memerlukan tingkat koordinasi yang tinggi".

Dengan demikian kepala sekolah merupakan guru yang diberikan tugas tambahan karena memiliki kemampuan yang lebih baik, maka dalam melaksanakan tugasnya perlu melibatkan semua pihak yang ada dalam lingkungan sekolah khususnya guru dalam menyukseskan segala program pembelajaran atau program lainnya yang disusun secara bersama-sama dengan dewan guru.

Peranan kepala sekolah sebagai pemimpin pendidikan yang mendapat kepercayaan untuk memimpin sekolah, perlu menyenangi dan mencintai pekerjaan yang terkait dengan tugas dan tanggung jawab yang dipercayakan kepadanya. Sagala (2011:115) mengatakan bahwa: “Seorang pemimpin mendesain pekerjaan beserta mekanismenya, didukung staf yang melaksanakan tugas sesuai dengan kemampuan dan keahliannya". keberhasilan sekolah, serta memiliki kepedulian kepada staf dan siswa" . Secara operasional kepala sekolah memiliki standar kompetensi untuk menyusun perencanaan strategis, mengelola tenaga kependidikan, mengelola kesiswaan, mengelola fasilitas, mengelola sistem informasi manajemen, mengelola regulasi atau peraturan pendidikan, mengelola mutu pendidikan, mengelola kelembagaan, mengelola kekompakan kerja (teamwork), dan mengambil keputusan.

Kenyataan menunjukkan bahwa pembinaan kompetensi guru yang dilaksanakan oleh kepala sekolah secara umum belum berjalan sesuai harapan. Oleh karena itu pembinaan kemampuan guru harus mendapat pembinaan lebih lanjut dan serius. Sebagaimana observasi awal peneliti pada SMA Negeri 1 Peukan Bada Aceh Besar merupakan salah satu sekolah yang memiliki prestasi siswa mulai tingkat lokal hingga nasional, akan tetapi masih ada guru yang masuk terlambat ke kelas, serta masih ada ruangan belajar yang kosong di saat jam belajar sedang berlangsung, karena guru tidak hadir, maka siswa berkumpul

\footnotetext{
${ }^{2}$ Mulyono, Manajemen Administrasi dan Organisasi Pendidikan (Yogyakarta: Ar Ruzz Media Group, 2008), hlm. 70.

${ }^{3}$ Syaiful Sagala, Konsep dan Makna Pembelajaran (Bandung: Alfabeta, t.t.), hlm. 70.
} 
FITRAH Jurnal Kajian Ilmu-ilmu Keislaman Vol. 04 No. 1 Juni 2018

di depan kelas atau di kantin. Dilain pihak tidak dapat dipungkiri ada guru-guru yang hadirnya cepat, namun siswanya yang terlambat hadir.

Melihat fenomena di atas, akar permasalahan itu bukan hanya pada guru sebagai pribadi, tetapi justru pada upaya pembinaan belum menekankan pada kesamaan visi, misi dan tujuan dari unsur-unsur terkait dengan kata lain strategi yang ditempuh oleh kepala sekolah belum mampu meningkatkan kompetensi guru, hal ini juga dialami oleh SMA Negeri 1 Peukan Bada Aceh Besar. Setiap proses pembelajaran guru mempunyai tujuan masing-masing untuk terlaksananya proses belajar mengajar dengan baik.

\section{KAJIAN PUSTAKA}

\section{Strategi Kepemimpinan Kepala Sekolah}

Suhardan (2014:146) mengemukakan bahwa: "Strategi adalah sarana bersama dengan tujuan jangka panjang yang hendak dicapai. Strategi dalam memperbaiki mutu pendidikan dan mutu pembelajaran melalui usaha yang memadai untuk meraih keberhasilan". Wahjosumidjo ${ }^{4}$ (2010: 17) mengatakan bahwa: "Kepemimpinan di terjemahkan ke dalam istilah sifat-sifat, perilaku pribadi, pengaruh terhadap orang lain, pola-pola, interaksi, hubungan kerja sama antar peran, kedudukan dari satu jabatan administratif, persuasif, dan persepsi dari lain-lain tentang legitimasi pengaruh.

Berdasarkan pengertian di atas, dapat disimpulkan bahwa strategi kepemimpinan adalah rencana atau cara yang dilakukan pemimpin untuk mencapai suatu tujuan tertentu. Tujuan dalam kaitannya dengan strategi kepemimpinan kepala sekolah/madrasah, maka dengan demikian tujuan yang akan dicapai sebagaimana dimaksud dalam penelitian ini yaitu untuk kemajuan suatu lembaga pendidikan dalam hal ini lembaga pendidikan pada jenjang sekolah menengah Atas yaitu SMA Negeri 1 Peukan Bada Aceh Besar.

\section{Kompetensi Guru}

Menurut Pasal 28 Ayat (3) Undang-Undang Sistem Pendidikan Nasional (UUSPN) tahun 2003, ada 4 kompetensi yang harus dimiliki seorang guru Pasal 42 ayat (1) UUSPN menyatakan guru memiliki kualifikasi minimum dan sertifikasi sesuai dengan jenjang kewenangan mengajar, sehat jasmani dan

\footnotetext{
4 Wahjosumidjo, Kepemimpinan Kepala Sekolah Tinjauan Teoritik dan Permasalahannya. Cetakan ke-7 (Jakarta: Rajawali Press, 2010), hlm. 17.
} 
rohani, serta memiliki kemampuan untuk mewujudkan tujuan pendidikan nasional. Pasal 28 ayat 3 Peraturan Pemerintah Nomor 19 Tahun 2005 tentang Standar Nasional Pendidikan secara tegas dinyatakan bahwa ada empat kompetensi yang harus dimiliki guru sebagai agen pembelajaran.

Guru sebagai jabatan profesional guru dituntut mempunyai beberapa kompetensi, dalam hal ini pemerintah telah merumuskan empat jenis kompetensi guru sebagaimana tertuang dalam Peraturan Pemerintah (PP) Tentang Standar Nasional Pendidikan Nomor 19 Tahun 2005 di antaranya kompetensi pedagogik, kompetensi kepribadian, kompetensi professional dan kompetensi sosial.

\section{Komponen Kompetensi}

Mulyasa 5 mengatakan bahwa: "Seorang guru harus mempunyai empat kompetensi dasar yaitu kompetensi pedagogik, kompetensi kepribadian, kompetensi sosial, dan kompetensi professional". Kompetensi guru dapat dirangkum menjadi empat bidang kompetensi mencangkup:

\section{a. Kompetensi Profesional}

Undang - Undang Nomor 14 Tahun 2005 tentang Guru dan Dosen pada pasal 1 ayat 1 dinyatakan bahwa Guru adalah pendidik profesional dengan tugas utama mendidik, mengajar, membimbing, mengarahkan, melatih, menilai, dan mengevaluasi peserta didik pada pendidikan anak usia dini, jalur pendidikan formal, pendidikan dasar dan pendidikan menengah. Kompetensi profesional merupakan suatu hal yang sangat penting bagi guru, karena ia harus memiliki keahlian di bidang mengajar, yakni menguasai bahan atau materi yang akan diajarkan kepada anak didiknya, di samping kemampuan-kemampuan lain yang menunjang terciptanya pembelajaran yang aktif, kreatif, dan dinamis.

Sebagai pekerjaan profesional, maka ciri dan karakteristik dari proses mengajar sebagai tugas profesional guru. Bahwa indikatorindikator kompetensi profesional adalah sebagai berikut:

1) Mengidentifikasikan aturan-aturan yang berkaitan dengan etika dan moral terhadap materi pelajaran.

\footnotetext{
${ }^{5}$ Mulyasa, Menjadi Kepala Sekolah Profesional dalam Konteks Menyukseskan MBS dan KBK (Bandung: Remaja Rosdakary, 2007), hlm. 17.
} 
FITRAH Jurnal Kajian Ilmu-ilmu Keislaman

Vol. 04 No. 1 Juni 2018

2) Mengidentifikasikan terhadap syarat-syarat kesehatan dan keselamatan kerja (K3) dalam mengunakan media pembelajaran.

3) Memahami ketentuan penggunaan strategi dalam media pembelajaran.

4) Menerapkan aturan yang berkaitan dengan etika dan moral dalam pembelajaran.

5) Menerapkan prinsip-prinsip kesehatan dan keselamatan kerja (K3) dalam mengunakan media pembelajaran.

6) Menghargai pentingnya hak atas kekayaan intelektual dalam pembelajaran.

7) Mengidentifikasikan perkembangan kurikulum.

8) Membuat lembar kerja dengan mengunakan program lembar kerja.

9) Membuat bahan presentasi.

10) Mampu mengedit, mengelola dan mencetak dokumen presentasi.

11) Membuat animasi dalam presentasi.

12) Membuat karya mengunakan program presentasi.

13) Menggunakan internet untuk memperolah dan mencari informasi.

\section{b. Kompetensi Personal}

Sebagaimana penjelasan Undang-Undang Nomor 14 Tahun 2005 tentang Guru dan Dosen Pasal 10 Ayat 1, yang dimaksud dengan kompetensi guru personal atau disebut juga dengan kepribadian adalah kemampuan kepribadian yang mantap, berakhlak mulia, arif dan berwibawa serta menjadi teladan peserta didik. Kompetensi personal adalah sikap pribadi guru yang berjiwa pancasila yang mengagungkan budaya bangsa Indonesia yang rela berkorban bagi kelestarian bangsa dan Negara. Kompetensi personal atau kepribadian menuntut guru melakukan beberapa hal berikut:

a) Selalu menampilkan diri sebagai pribadi yang mantap, stabil, dewasa, arif, dan berwibawa.

b) Selalu menampilkan diri sebagai pribadi yang berakhlak mulia yang menjadi teladan bagi peserta didik.

c) Selalu berperilaku sebagai pendidik profesional.

d) Mengembangkan diri terus menerus sebagai pendidik profesional. 
e) Mampu menilai kinerja sendiri yang berkaitan dengan pencapaian tujuan utuh pendidikan.

Dari beberapa uaraian di atas, maka kompetensi personal yang mutlak harus dimiliki oleh seorang guru untuk menunjang pelaksanaan tugasnya dalam proses pembelajaran adalah adanya kemantapan dan integritas pribadi, berfikir alternatif, adil, jujur dan objektif, berdisiplin dalam menjalankan tugas, ulet dan tekun bekerja, simpatik dan menarik, luwes, bijaksana dan sederhana dalam bertindak, bersifat terbuka, kreatif dan berwibawa.

\section{c. Kompetensi Sosial}

Sebagaimana penjelasan Undang-Undang Nomor 14 Thaun 2005 tentang Guru dan Dosen pada pasal 10 Ayat 1 kompetensi sosial adalah kemampuan guru untuk berkomunikasi dan berinteraksi secara efektif dan efisien dengan peserta didik, sesama guru, orang tua/wali peserta didik dan masyarakat sekitar. Dalam Standar Nasional Pendidikan (SNP) Tahun 2013 pasal 28 ayat (3) butir d, Kompetensi sosial adalah kemampuan guru sebagai bagian dari masyarakat untuk berkomunikasi dan bergaul secara efektif dengan peserta didik, sesama pendidik, tenaga kependidikan, orang tua/wali dan masyarakat. Cece dan Tabrani (2008) mengemukakan empat jenis kompetensi sosial yang harus dimiliki oleh guru sebagai berikut:

1) Terampil berkomunikasi dengan orang tua anak didik.

2) Bersikap simpatik

3) Dapat bekerja dengan BP3/Komite sekolah

4) Pandai bergaul dengan kawan sekerja dan mitra pendidikan

Dari uraian di atas, terlihat bahwa guru diharapkan menjadi figur yang dihormati yang dapat berinteraksi dengan anak didik, orang tua maupun masyarakat dengan baik sehingga akan terjalin kerja sama yang erat antara sekolah dan masyarakat.Arikunto ${ }^{6}$ mengemukakan bahwa: "kualitas kegiatan pembelajaran sebagai salah satu faktor penting penentu prestasi belajarnya". Dengan demikian adanya jalinan sosial melalui komunikasi yang baik dengan peserta didik, maka hasilnya sangat positif.

\footnotetext{
2013), hlm. 4.
}

${ }^{6}$ Suharsimi Arikunto, Prosedur Penelitian: Suatu Pendekatan Praktik (Jakarta: Rineka Cipta, 
FITRAH Jurnal Kajian Ilmu-ilmu Keislaman

Vol. 04 No. 1 Juni 2018

\section{d. Kompetensi Pedagogik}

Yang dimaksud dengan kompetensi pedagogik adalah kemampuan mengelola pembelajaran peserta didik. (Penjelasan UndangUndang Nomor 14 Tahun 2005 tentang Guru dan Dosen Pasal 10 Ayat 1) Jadi kompotensi pedagogik adalah kemampuan mengelola peserta didik yang meliputi pemahaman terhadap peserta didik, perencangan dan pelaksanaan pembelajaran, evaluasi hasil belajar, serta pengembangan peserta didik untuk mengaktualisasikan berbagai potensi yang dimiliki. Adapun kompetensi pedagogik itu sendiri meliputi:

1) Mampu memutuskan mengapa, kapan, dimana, dan bagaimana tujuan, materi, strategi, media dan evaluasi mendukung tujuan pengajaran, dan bagaimana memilih jenis-jenis komponen tersebut yang sesuai keperluan belajar siswa.

2) Mampu mengembangkan potensi peserta didik.

3) Menguasai prinsip-prinsip dasar pembelajaran.

4) Mengembangkan kurikulum yang mendorong keterlibatan peserta didik dalam pembelajaran.

5) Merancang pembelajaran yang mendidik.

6) Melaksanakan pembelajaran yang mendidik.

7) Menilai proses dan hasil pembelajaran yang mengacu pada tujuan utuh

8) pendidikan.

9) Menilai proses dan hasil pembelajaran yang mengacu pada tujuan utuh pendidikan.

Pentingnya kompetensi guru tersebut diatas baik kompetensi guru professional, personal, sosial dan pedagogik, sebagaimana telah dibahas diatas adalah untuk meningkatkan kualitas guru. Untuk mendapatkan kualitas dimaksud maka perlu dilaksanakannya uji kompetensi guru,baik secara teoritis maupun dalam tataran praktis memiliki manfaat yang sangat penting terutama dalam meningkatan kualitas pendidikan melalui kualitas guru.

\section{Peran, Fungsi dan Tanggung Jawab Kepala Sekolah}

Kepala sekolah yang berhasil adalah mereka yang memahami keberadaan sekolah sebagai organisasi yang komplek dan unik, serta mampu 
melaksanakan peranan kepala sekolah sebagai seorang pemimpin yang diberi tanggung jawab untuk memimpin sekolah. Wahyudi ${ }^{7}$ mengatakan bahwa: "Kepala sekolah didefinisikan sebagai seorang tenaga fungsional guru yang diberi tugas untuk memimpin suatu madrasah dimana diselenggarakan proses belajar mengajar, atau tempat dimana terjadi interaksi antara guru yang memberi pelajaran dan murid yang menerima pelajaran".

Salah satu faktor yang menentukan keberhasilan dan keberlangsungan organisasi adalah kuat tidaknya kepamimpinan, kegagalan dan keberhasilan suatu organisasi ditentukan oleh pemimpin karena pemimpin merupakan pengendali dan penentu arah yang hendak ditempuh menuju tujuan yang akan dicapai. Fungsi dan tanggung jawab kepala sekolah sebagai pemimpin lembaga pendidikan akan menjadi efektif apabila menjalankan proses kepemimpinannya yang mendorong, mempengaruhi dan menggerakkan kegiatan dan tingkah laku kelompoknya.

Kepala sekolah memiliki dua tanggung jawab ganda yaitu: 1) melaksanakan administrasi sekolah sehingga dapat tercipta situasi belajar yang baik. 2) melaksanakan supervisi pendidikan agar memperoleh peningkatan kegiatan mengajar guru dalam membimbing pertumbuhan peserta didik. Mulyadi ${ }^{8}$ mengatakan bahwa dengan keterampilan tersebut, diharapkan kepala sekolah dapat melaksanakan tugas secara efektif dan efesien

Seorang kepala sekolah tidak hanya bertanggung jawab atas kelancaran sekolah secara teknis akademis saja, melainkan juga bertanggung jawab dengan kondisi dan situasinya serta hubungannya dengan masyarakat sekitarnya. Peranannya dipengaruhi oleh kepribadiannya, persiapan dan pengalaman profesionalnya, serta ketetapan yang dibuat oleh madrasah mengenai peranan kepala madrasah di bidang pengajaran. Pelayanan pendidikan dalam dinas bagi administrator madrasah dapat memperjelas harapan atas peranan kepala sekolah.

\footnotetext{
${ }^{7}$ Wahyudi, Kepemimpinan Kepala Sekolah Dalam Organisasi Pembelajaran, hlm. 20.

${ }^{8}$ Mulyadi, Sistem Akuntansi, Edisi ke-3, Cetakan ke-5 (Jakarta: Penerbit Salemba Empat, 2010), hlm. 59.
} 
FITRAH Jurnal Kajian Ilmu-ilmu Keislaman

Vol. 04 No. 1 Juni 2018

\section{Hambatan Kepala Sekolah untuk Meningkatkan Kompetensi Guru}

Secara umum bahwa kendala-kendala dalam pelaksanaan supervisi pendidikan di sekolah antara lain:

a. Sistem pembinaan yang kurang memadai, karena pembinaan lebih menekankan pada administrasi dan melalui aspek profesional, kurangnya tatap muka antara pembina dan guru, kurangnya bekal tambahan pengetahuan dari pembina, sehingga tidak dapat mengikuti perkembangan baru dalam berbagai mata pelajaran, pembinaan yang masih menggunakan jalur tunggal dari atas ke bawah, dan potensi guru sebagai pembina rekan lain kurang didaya gunakan. Seharusnya pembinaan juga dapat dilakukan antar sesama guru, misalnya melalui sharing sesama guru terhadap kesulitan dalam pembelajaran.

b. Sikap mental yang kurang menunjang, misalnya: hubungan professional yang kaku antara "atasan" dan "bawahan", akibat sifat ototiter pembina tertentu, sehingga guru ikut dan kurang terbuka terhadap pembina.

c. Kurangya koordinasi kegiatan pembinaan dari berbagai pihak yang berwenang di lapangan, baik secara vertikal maupun horizontal, sehingga kadang- kadang membingungkan para guru.

Hambatan yang dihadapi Kepala sekolah dalam rangka upaya peningkatan profesionalisme guru, antara lain: Pengetahuan akan sistem kinerja oleh guru relatif kurang, kedisiplinan guru dalam pembelajaran siswa relatif lemah, dan perangkat administrasi pembelajaran relatif berat. Hal telah diupayakan suatu solusinya melalui pembinaan pengetahuan dan keterampilan teknis lewat pemberdayaan kompetensi guru, mendengarkan masukan tentang pentingnya suatu kedisiplinan dalam melaksanakan proses pembelajaran secara rutinitas, agar guru dapat mematuhi aturan sekolah dan aturan kepegawaian yang mengikat.

\section{METODE PENELITIAN}

Jenis penelitian yang digunakan adalah rancangan penelitian deskriptif, yaitu suatu metode untuk meneliti status kelompok manusia, suatu objek, suatu kondisi, suatu sistem pemikiran ataupun suatu kelas peristiwa pada masa sekarang (Moh Ainin, 2010:71). Metode penelitian ini dipilih untuk mengungkapkan strategi kapala sekolah dalam meningkatkan kompetensi guru. Tahap-tahapan dalam pelaksanaan penelitian ini memberikan gambaran tentang 
keseluruhan perencanaan, pelaksanaan, pengumpulan data, sampai dengan penyusunan pelaporan.

Dalam pengumpulan data peneliti menggunakan 2 teknik pengumpulan data yaitu observasi dan wawancara, sertadokumentasi. Bentuk wawancara yang akan digunakan adalah wawancara langsung dan tidak terstruktur, dimana peneliti tidak menggunakan pedoman wawancara yang telah disusun secara sistematis dan lengkap sebagai pengumpul data.

\section{HASIL PENELITIAN DAN PEMBAHASAN}

1. Program Kepala Sekolah untuk Meningkatkan Kompetensi Guru SMA Negeri 1 Peukan Bada Kabupaten Aceh Besar.

Berdasarkan uraian hasil wawancara menunjukkan bahwa kemampuan kepala sekolah dalam mengambil keputusan adalah melibatkan semua unsur yang berkepentingan agar terjadi suatu keputusan bersama dan bukan keputusan kepala sekolah saja. Apa pun keputusan yang diambil kepala sekolah pasti memiliki makna penting, baik bagi orang lain maupun terhadap diri sendiri. Kecil atau pun besar volume kelompok yang dipimpinnya, keputusan pemimpin sangatlah berarti, serius, serta berpengaruh besar dan luas. Kenyataan itu memberikan dampak terhadap indikasi bahwa keputusan harus diambil tidak saja dengan hati-hati, tapi juga tegas dan diputuskan dengan berani dalam keadaan sadar. Artinya sebagai pimpinan, kepala sekolah perlu melibatkan pihak lain dalam mengambil setiap keputusan penting.

Kepala SMA Negeri 1 Peukan Bada Kabupaten Aceh Besar menyusun program dalam meningkatkan kompetensi guru dalam bentuk program tahunan dan jabarkan dalam program semester. Program peningkatan kompetensi guru dirumuskan sebelum tahun ajaran baru bersama tim pengembangan sekolah sesuai dengan surat keputusan sekolah. Tim pengembangan sekolah meliputi kepala dan wakil kepala sekolah, pengawasan sekolah, komite dan beberapa guru senior di sekolah.

Dalam proses penyusunan program untuk meningkatkan kompetensi guru, tim hanya melihat pengembangan hasil pelaksanaan program dengan program yang direncanakan tahun sebelumnya. Hasil evaluasi tersebut menjadi pertimbangan dan menyusun program tahun berikutnya. Program tahunan dan program semester disusun memuat kepala sekolah langsung 
FITRAH Jurnal Kajian Ilmu-ilmu Keislaman

Vol. 04 No. 1 Juni 2018

menentukan jadwal, instrument, program, intensitas tatap muka, waktu pelaksanaan, tujuan yang ingin dicapai, dan pendekatan yang akan dilakukan.

Program sekolah yang kami rencanakan pada setiap awal tahun peajaran baru adalah melakukan pembinaan kepada guru secara rutin berupa pembinaan rentang penyusunan rencana pelaksanaan pembelajarabn (RPP), Pelaksanaan pembelajaran dan evaluasi pembelajaran melaksanakan supervisi kelas dan melaksanakan MGMP di sekolah. Program sekolah tersebut dijabarkan dalam program tahunan dan program semester. Hasil observasi penulis tentang dokumentasi program tahunan SMA Negeri 1 Peukan Bada Kabupaten Aceh Besar bahwa program tahunan sudah terdokumentasi dengan baik.

Dalam upaya mewujudkan program-program yang telah disusun oleh kepala sekolah, maka kepala sekolah membentuk organisasi guru berupa MGMP. Melalui organisasi ini, guru diharapkan terjalinya hubungan yang baik dengan kepala sekolah, wakil kepala sekolah dan sesama guru mata pelajaran. Guru dapat berdiskusi tentang permasalahan dan solusi dari setiap permasalahan yang dihaapi guru, dan saling sharing terhadap pendidikan. Program ini dimaksudkan untuk mendayakan seluruh sumber daya organisasi dalam rangka mencapai tujuan yang telah ditetapkan.

Upaya kepala sekolah untuk mengatifkan kegiatan ini, maka kepala sekolah bersama ketua MGMP membudayakan kepada guru untuk saling terbuka dan komunikatif dalam penyampaian hal-hal yang dianggap menjadi tantangan. Kegiatan MGMP membudayakan kepada guru untuk menyusun perangkat pembelajaran yang lengkap. Sehingga kegiatan pemeblajaran terararh dengan baik sesuai dengan program yang telah dibuat. Kemudian program tersebut diupayakan dengan semaksimal mungkin untuk dilaksanakan sesuai dengan rencana yang telah diprogramkan.

Berpijak pada penjelasan di atas menunjukkan bahwa Kepala Sekolah telah menyusun program tertulis dan selalu dijalankan program rutin supervisi setiap awal semester ganjil dan semester genap. Pelaksanaan program supervisi sudah dilakukan walaupun belum optimal. Dan dalam menyusun program supervisi secara tertulis Kepala Sekolah selalu berpedoman pada manajemen supervisi yang diawali oleh perencanaan program supervisi yang baik. 


\section{Pelaksanaan Program Kepala Sekolah untuk Meningkatkan Kompetensi} Guru SMA Negeri 1 Peukan Bada

Kepala Sekolah adalah pemimpin tertinggi di sekolah. Pola kepemimpinan akan sangat berpengaruh bahkan sangat menentukan terhadap kemajuan sekolah.oleh karena itu, dalam pendidikan modern, kepemimpinan kepala sekolah perlu mendapat perhatian serius. Kepemimpinan dimaksud kepala sekolah adalah cara usaha kepala sekolah dalam mempengaruhi, mendorong, membimbing, megarahkan, dan menggerakkan guru, staf, peserta didik orang tua peserta didik, dan pihak lain yang terkait, untuk bekerja/berperan serta guna mencapai tujuan yang telah ditetapkan. Singkatnya, bagaimana cara kepala sekolah untuk membuat bawahannya bekerja untuk mencapai tujuan sekolah.

Sebagai pengelola pendidikan kepala sekolah bertanggung jawab terhadap keberhasilam penyelenggaraan kegiatan pendidikan dengan cara melaksanakan administrasi sekolah dengan seluruh substansinya. Bertanggung jawab terhadap kualitas sumber daya manusia yang ada agar mereka mampu menjalankan tugas-tugas pendidikan. Kepala sekolah dalam membina bawahan, utamanya para guru sangat dituntut, sebab guru merupakan alat utama dalam menciptakan tujuan pembelajaran di sekolah. Dari seorang gurulah ilmu pengetahuan dan agama akan mengalir ke siswa. Karenanya dalam mencapai tujuan pembelajaran yang efektif dan efisien, kepala sekolah sangat dituntut untuk meningkat-kan profesionalisme guru.

Kepala sekolah dalam memimpin sebuah lembaga pendidikan harus mempunyai kompetensi sebagai seorang administrator. Sebagai administrator kepala sekolah bekerjasama dengan orang dalam lingkungan pendidikan (sekolah). Ia melibatkan komponen manusia dengan berbagai potensinya, dan juga komponen manusia dengan berbagai jenisnya. Semuanya perlu ditata dan dikoordinasikan atau didayagunakan untuk mencapai tujuan pendidikan dalam sebuah aturan-aturan.

Berdasarkan uraian hasil wawancara menunjukkan bahwa kepala sekolah mengatur aktivitas kerja di sekolah dilakukan sesuai dengan tupoksi masing-masing. Melalui pertemuan bersama dalam suatu rapat, kepala sekolah membicarakan berbagai kegiatan kerja mulai dari perencanaan, pengorganisasian, dan bagaimana pelaksanaannya. Tapi pengontrolan dalam aktivitas kerja sekolah yang telah direncanakan bersama kepala sekolah masih 
FITRAH Jurnal Kajian Ilmu-ilmu Keislaman

Vol. 04 No. 1 Juni 2018

perlu ditingkatkan sebagai bagian untuk mengevaluasi kegiatan demi menciptakan efesiensi terlaksananya suatu kegiatan sekolah.

Kepala SMA Negeri 1 Peukan Bada Kabupaten Aceh Besar melaksanakan kegiatan peningkatan kompetensi guru setelah selesai menyusun seluruh program sekolah tersebut. Pelaksanaan program diawali dengan pembagian tugas sesaui dengan kemampuan dan keahlian masingmasing. Setiap guru harus menjalankan tugas tersebut dengan sebaik-baiknya dan tepat waktu berdasarkan jadwal yang sudah disepakati dan ditentukan. Pelaksanaan kegiatan menerapkan kerjasama antara sesama guru secara berkala untuk menumbuhkan budaya sekolah yang harmonis. Pelaksanaan program dilaksanakan belum semuanya berdasarkan jadwal yang tercantum pada dokumentasi perencanaan sekolah.

Dalam melaksanakan program, kepala sekolah tidak semuanya menyiapkan instrumennya. Sebagaimana instrument tersebut didokumentasikan dalam pelaksanaan kegiatan oleh kepala sekolah. Instrument yang digunakan hanya instrument pelaksanaan supervisi yang meliputi instrument perangkat perencanaan pembelajaran, instrument proses belajar mengajar dan instrument evaluasi pemeblajaran.

Hasil observasi penulis bahwa instrument perangkat pembelajaran meliputi: Minimal (KKM) Rencana Pelaksanaan Pembelajaran (RPP) yang terdiri dari kegiatan awal, kegaiatan inti dan kegaiatan akhir, lembar kerja siswa (LKS) serta instrument penilaian yang digunakan oleh guru. Observasi penulis terhadap instrument pelaksanaan pembelajaran (Pendahuluan) kegiatan inti dan kegiatan akhir (penutup). Kegiatan pendahuluan memuat menyiapkan peserta didik, melakukan apersepsi menjelaskan KD dan tujuan yang ingin dicapai, menyampaikan cakupan materi dan penjelasan uraian kegiatan sesuai silabus/kesiapan bahan ajar dan penampilan guru.

Kegiatan inti pada instrument supervisi kegiatan pembelajaran melalui pengamatan, menanya, mencoba, menalar, dan mengkomunikasikan. Hal ini menandakan bahwa kurikulum yang digunakan di SMA Negeri 1 Peukan Bada Kabupaten Aceh Besar ini sudah mengunakan Kurikulum 2013. Pelaksaan supervisi berupa observasi dan kunjungan kelas dilakukan secara tiba-tiba dan juga ada pemberitahuan terlebih dahulu. Umumnya guru sudah siap ketika kepala sekolah masuk ke dalam kelas, melakukan supervisi individual berupa kunjungan kelas. Kegiatan yang dilakukan oleh kepala 
sekolah ketika melaksanakan supervisi adalah memantau pelaksanaan belajar mengajar, memeriksa kelengkapan pembelajaran dan memberikan arahan ketika selesai pembelajaran.

Ketersediaan fasilitas belajar di sekolah yang lengkap dan memadai juga merupaka indikasi atau syarat menjadi sekolah yang efektif. Sekolah akan menjadi sekolah yang mempunyai mutu baik jika dalam penyelenggaraan kegiatan belajarnya tidak hanya didukung oleh potensi siswa, kemampuan guru dalam mengajar ataupun oleh lingkungan sekolah, akan tetapi juga harus didukung adanya perlengkapan fasilitas belajar siswa yang memadai sehingga penggunaanya akan menunjang kemudahan siswa dalam kegiatan belajarnya.

Kepala sekolah selalu menyarankan dan memberikan arahan kepada seluruh guru agar mampu menguasi pngetahuan yang diampunya meliputi penguasan materi pelajaran secara luas dan mendalam sesuai standar isi program satuan pendidikan, mata pelajaran, kelompok mata pelajaran yang akan diampunya, mengerti dan dapat menerapkan teori sesuai taraf perkembangan peserta didik, mampu menangani dan mengambangkan bidang studi yang menjadi tanggung jawabnya, mengerti dan dapat metode pembelajaran yang bervariasi, mampu mengembangkan dan menggunakan sebagai alat, media, dan sumber belajar yang relevan, mampu mengorganisasi dan melaksanakan program pembelajaran, dan mampu melaksanakan evaluasi hasil belajar peserta didik.

Dalam proses pelaksanaan program peningkatan kompetensi guru, kepala sekolah melakukan pendekatan kekeluargaan. Pendekatan ini dimaksudkan untuk terjalinnya hubungan yang harmonis dan bersifat terbuka, sehinnga masing-masing bekerja sesuai dengan tugas dan fungsinya masing-masing.

Salah satu peran kepala sekolah yakni melakukan suatu usaha untuk membantu para guru dalam meningkatkan pertumbuhan pribadi dan jabatannya dan juga para staf sekolah lainnya agar anak didik dapat belajar secara lebih baik dalam situasi proses mengajar secara lebih efektif dan efisien. Sehingga pengembangan kompetensi pada diri seorang harus didukung oleh adanya peran kepala sekolah yang efektif dan efisien. Dan jika seorang guru yang mengalami kesulitan untuk mengembangkan kompetensi dirinya ada yang membantu dirinya untuk mengembangkannya. 
FITRAH Jurnal Kajian Ilmu-ilmu Keislaman

Vol. 04 No. 1 Juni 2018

Mengikutkan guru dalam Kegiatan Pendidikan dan Pelatihan Tenaga Guru (PPTG) dan tenaga kependidikan pada umumnya. Hal ini dimaksudkan agar guru mampu merespon perubahan dan tuntutan perkembangan IPTEK dan kemajuan kemasyarakatan, termasuk perubahan sistem pendidikan dan pembelajaran secara mikro. Adanya kegiatan pelatihan atau workshop terhadap peningkatan kompetensi guru merupakan langkah positif dalam rangka melahirkan pendidikan yang berkualitas, sehingga guru selalu terubdate ilmunya.

Pelaksanaan program peningkatan kompetensi guru secara umum sudah terlaksana secara optimal. Hal ini sebagaimana hasil wawancara dan observasi peneliti serta data dokumentasi yang ada ketika peneliti melakukan penelitian sudah optimalnya pelaksanaan program karena sudah terlaksananya semua program yang sudah direncanakan secara umum, kegiatan sudah sesuai dengan rencana, begitu juga dengan kegiatan supervisi yang dilaksanakan sudah sesuai dengan apa yang diharapkan.

3. Evaluasi Kepala Sekolah dalam Meningkatkan Kompetensi Guru SMA Negeri 1 Peuakn Bada.

Dalam kegiatan ini kepala sekolah selalu melakukan pembinaan kepada guru untuk memahami kegiatan penilaian, apakah melalui penyusunan program evaluaisi, penyediaan buku-buku petunjuk penilaian maupun dengan mendorong mengkaji dalam kelompok MGMP. Kepala sekolah sebagai supervisor mempunyai peran dan tanggung jawab memantau, membina, dan memperbaiki proses belajar mengajar di kelas atau di sekolah. Supervisi sebagai upaya pemberian bantuan kepada guru untuk mewujudkan situasi belajar yang lebih baik. Untuk mengetahui sejauhmana guru mampu melaksanakan pembelajaran, kepala sekolah perlu melaksanakan kegiatan supervisi secara berkala yang dapat dilakukan melalui kunjungan kelas untuk mengamati proses pembelajaran secara langsung.

Kegiatan supervisi tersebut untuk mengetahui bagaimana guru dalam memilih dan menggunakan metode, media yang digunakan dan keterlibatan siswa dalam proses pembelajaran. Melalui hasil supervisi ini dapat diketahui kelemahan sekaligus keunggulan guru dalam melaksanakan pembelajaran, tingkat penguasaan kompetensi guru yang bersangkutan, selanjutnya diupayakan solusi pembinaan dan tindak lanjut tertentu, sehingga guru dapat 
memperbaiki kekurangan yang ada, sekaligus mempertahankan keunggulan dalam melaksanakan pembelajaran.

Berdasarkan gambaran di atas menunjukkan bahwa kepala sekolah telah telah berupaya memberikan motivasi kepada guru-guru supaya dapat menganalisi hasil evaluasi dan membuat program perbaikan dan pengayaan secara berkelompok diluar jam tatap muka. Upaya diatas hanya sebatas mendorong dan menyediakan buku petunjuk, sementara upaya kongkrit belum diterima oleh guru.

\section{Hambatan-hambatan yang Dihadapi oleh Kepala Sekolah untuk Meningkatakan Kompetensi Guru pada SMA Negeri 1 Peukan Bada.}

Pendidikan merupakan masalah yang sangat penting dalam kehidupan manusia, karena pendidikan memiliki cakupan yang sangat luas, yaitu selain mengasuh, mendidik atau memelihara anak, pendidikan juga merupakan pengembangan keterampilan, pengetahuan maupun kepandaian melalui pengajaran latihan-latihan atau pengalaman, lebih jauh pendidikan juga dapat mengembangkan intelektual dan kepribadian yang dilakukan secara bertahap. Dalam hal ini, peran kepala sekolah memiliki peran penting dan nilai strategis dalam meningkatkan kompetensi guru.

Dalam melaksanakan usahanya untuk meningkatkan kinerja guru kepala sekolah juga menemukan beberapa kendala dilapangan, hal ini sesuai dengan apa yang di utarakanya, yaitu: dalam kaitan peningkatan kinerja guru di madrasa yang kami pimpin, kami menemukan sedikit kendala yaitu, rendahnya kualitas sumberdaya manusia (SDM), Kurangnya kesadaran guru dalam menegakkan kedisiplinan dan rendahnya kesadaran siswa kedisiplinan.

Kepala sekolah sebagai unsur vital bagi efektivitas dalam lembaga pendidikan menentukan tinggi rendahnya kwalitas lembaga tersebut, kepala sekolah diibaratkan sebagai panglima pendidikan yang melaksanakan fungsi kontrol berbagai pola kegiatan pengajaran dan pendidikan didalamnya, oleh kerana itu suksesnya sebuah sekolah tergantung pada sejauh mana pelaksanaan misi yang dibebankan diatas pundaknya, kepribadian, dan kemampuannya dalam bergaul dengan unsurunsur yang ada didalamnya.

Berdasarkan uraian hasil penelitian menunjukkan strategi kepala sekolah dalam menyelesaikan beberapa masalah pendidikan yang ada di sekolah 
FITRAH Jurnal Kajian Ilmu-ilmu Keislaman

Vol. 04 No. 1 Juni 2018

adalah dengan mengelola berbagai sumber daya pendidikan yang sudah ada di sekolah dan juga yang ada pada masyarakat.

\section{DISKUSI HASIL PENELITIAN}

Pembahasan diuraikan berdasarkan pertanyaan penelitian dan dibahas berdasarkan hasil penelitian. Adapun pembahasan yang dibahas tentang program kepala sekolah untuk meningkatkan kompetensi guru, pelaksanaan program dalam meningkatkan kompetensi guru, evaluasi kepala sekolah dalam meningkatkan kompetensi guru serta hambatan-hambatan yang dihadapi dalam meningkatkan kompetensi guru di SMA Negeri 1 Peukan Bada Kabupaten Aceh Besar. Adapun masing-masing fokus pembahasan secara rinci dibahas sebagai berikut:

\section{Program Kepala Sekolah dalam Meningkatkan Kompetensi Guru pada SMA Negeri 1 Peukan Bada}

Hasil penelitian menunjukkan bahwa program kepala sekolah dalam meningkatkan kompetensi guru pada SMA Negeri 1 Peukan Bada Kabupaten Aceh Besardisusun pada setiap awal semester atau awal tahun pelajaran oleh tim pengembang sekolah yang meliputi program tahunan dan program semester dan sudah terdokumentasi dengan baik dan rapi di ruang tata usaha. Program itu sendiri yang sudah direncanakan adalah pembinaan bagi guru dalam rangka peningkatan kompetensi secara menyeluruh dan umumnya berkaitan dengan pembelajaran yang berkualitas yang dimulai dari RPP.

2. Pelaksanaan Program Kepala Sekolah dalam Meningkatkan Kompetensi Guru pada SMA Negeri 1 Peukan Bada

Berdasarkan hasil penelitian bahwa pelaksanaan program kepala sekolah dalam meningkatkan kompetensi guru pada SMA Negeri 1 Peukan Bada Kabupaten Aceh Besardiawali dengan menyampaikan arahan pada setiap awal semester. Dalam melaksanakan manajemen sekolah strategi kepala sekolah/sekolah menerapkan dengan prinsip kekeluargaan, namun tetap mengacu adanya penghargaan bagi yang selalu meningkatkan kompetensinya sebagai guru dan adanya teguran bagi guru yang kurang peduli terhadap peningkatan kompetensinya.

Pelaksanaan pembinaan terhadap guru harus benar-benar dilaksanakan dengan baik, kepala sekolah sebagai supervisor dalam upaya 
meningkatkan kinerja guru dapat menggunakan beberapa strategi dibawah ini antara lain:

a. Mengikutsertakan guru-guru dalam penataran-panataran untuk menambah wawasan.

b. Memberi kesempatan guru untuk meningkatkan pengetahuan dan ketrampilannya dalam mengajar ke jenjang yang lebih tinggi.

c. Membimbing guru dalam hal-hal yang berkaitan dengan perencanaan dan pelaksanaan program pembelajaran dan bimbingan konseling, penilaian hasil belajar peserta didik dan layanan analisis hasil penilaian belajar serta pengembangan program melalui kegiatan pengayaan dan perbaikan pembelajaran.

d. Memberikan kesempatan guru mengikuti berbagai pendidikan dan pelatihan di tingkat gugus atau kecamatan secara teratur, musyawarah guru mata pelajaran (MGMP), musyawarah guru pembimbing (MGP), dan kelompok kerja guru (KKG), serta diskusi seminar lokakarya, dan penyediaan sumber belajar. Yang bertujuan memperluas wawasan dan pengetahuan guru dalam berbagai hal, khususnya penguasaan subtansi materi pembelajaran, menyusun silabus, penyusunan bahan-bahan pembelajaran, dan terkait dengan strategi pembelajaran, metode pembelajaran, memaksimalkan pemakaian sarana dan prasarana belajar, serta meningkatkan kompetensi guru.

e. Mengirimkan guru ke Balai pendidikan dan pelatihan (Diklat)

Kepala sekolah dalam meningkatkan dalam meningkatkan kualitas pembelajaran di sekolahnya terlebih dahulu kepala sekolah menjalin hubungan yang akrab dengan guru, kemudian kepala sekolah memberikan pelayanan atau bantuan kepada guru, faktor pendukung adalah sarana dan prasarana yang memadai, adanya dukungan para guru dalam pelaksanaan supervisi, serta hubungan baik para guru dangan kepala sekolah adapun faktor penghambatnya adalah pelaksanaan supervisi sebagai penghambat proses belajar mengajar karena pelaksanaan supervisi berjalan lama, banyaknya acara yang melibatkan guru dan anak didik serta berbagai kegiatan dinas. 
FITRAH Jurnal Kajian Ilmu-ilmu Keislaman

Vol. 04 No. 1 Juni 2018

\section{Evaluasi Kepala Sekolah dalam Meningkatkan Kompetensi Guru pada SMA Negeri 1 Peukan Bada}

Hasil penelitian menunjukkan bahwa evaluasi kepala sekolah dalam meningkatkan kompetensi guru melalui proses tahapan-tahapan sendiri. Kegiatan supervisi tersebut untuk mengetahui bagaimana guru dalam memilih dan menggunakan metode, media yang digunakan dan keterlibatan siswa dalam proses pembelajaran. Melalui hasil supervisi ini dapat diketahui kelemahan sekaligus keunggulan guru dalam melaksanakan pembelajaran, tingkat penguasaan kompetensi guru yang bersangkutan, selanjutnya diupayakan solusi pembinaan dan tindak lanjut tertentu, sehingga guru dapat memperbaiki kekurangan yang ada, sekaligus mempertahankan keunggulan dalam melaksanakan pembelajaran.

Dari beberapa peran kepala sekolah dapat disimpulkan bahwa tugas kepala sekolah sebagai supervisor adalah merencanakan usahausaha untuk memperbaiki kekeliruan guru, mengkoordinasi sarana yang tidak dapat dilakukan sendiri oleh guru, mengarahkan guru yang kurang berdedikasi, dan mengontrol pekerjaan guru tersebut.

Keberhasilan kepala sekolah sebagai supervisor dapat ditunjukkan oleh (1) peningkatan kesadaran tenaga kependidikan (guru) untuk meningkatkan kinerjanya (2) meningkatkan ketrampilan tenaga kependidikan (guru) dalam melaksanakan tugasnya. Mengenai kemampuan kepala sekolah melaksanakan supervisi diharapkan mampu mengidentifikasi para guru yang bermasalah atau yang kurang profesional dalam melaksanakan tugas, sehingga pada akhirnya diketahui titik kelemahan yang menghambat pencapaian tujuan pendidikan untuk selanjutnya dicarikan solusi.

Kepala sekolah dalam melaksanakan perannya sebagai supervisor akan banyak menghadapi kendala, hal ini menuntut seorang supervisor untuk lebih mempersiapkan dirinya agar perannya dapat berjalan dengan baik serta melahirkan guru-guru yang dapat membawa pada peningkatan dalam pembelajaran.

Kepemimpinan sekolah yang baik akan mendorong keefektifitas manajemen sekolah dalam mencapai tujuan. Kepala sekolah sebagai pemimpin lembaga pendidikan harus memahami pula langkah-langkah pokok organisasi dan manajemen, yang merupakan kegiatan-kegiatan pokok untuk dijalankan oleh setiap guru dan staf. Kepala sekolah merupakan motor 
penggerak bagi sumber daya sekolah, dalam hal ini para guru perlu digerakkan kearah suasana kerja yang positif, menggairahkan dan produktif,hal ini disebabkanguru merupakan input yang pengaruhnya sangat besar pada proses belajar. Bahwa keberadaan kompetensi kepribadian, pedagogik, profesional, dan sosial sudah berfungsi dengan sangat maksimal. Baik dari segi mutu pendidikan dan mutu guru itu sendiri.

\section{Hambatan-hambatan yang Dihadapi Kepala Sekolah dalam Meningkatkan} Kompetensi Guru pada SMA Negeri 1 Peukan Bada

Hasil penelitian menunjukkan bahwa dalam melaksanakan usahanya, kepala sekolah untuk meningkatkan kinerja guru kepala sekolah juga menemukan beberapa kendala dilapangan, hal ini sesuai dengan apa yang di utarakanya, yaitu: dalam kaitan peningkatan kompetensi guru di sekolah yang kami pimpin, kami menemukan sedikit kendala yaitu, rendahnya kualitas sumberdaya manusia (SDM), Kurangnya kesadaran guru dalam menegakkan kedisiplinan dan rendahnya kesadaran siswa kedisiplinan.

Seorang pimpinan dalam menerapkan suatu strategi harus menganalisis yang tepat tentang kekuatan yang dimiliki oleh organisasi, kelemahan yang mungkin melekat pada dirinya, berbagai peluang yang mungkin timbul dan harus dimanfatkan serta ancaman yang diperkirakan akan dihadapi. Selanjutnya seorang pimpinan harus memperhatikan pentingnya operasionalisasi keputusan dasar yang dibuat dengan memperhitungan kemampuan organisasi dibidang anggaran, sarana, prasarana dan waktu, terakhir menciptakan umpan balik sebagai instrument ampuh bagi semua pihak yang terlibat dalam pelaksanaan strategi yang telah ditentukan itu untuk mengetahui apakah sasaran terlampaui, hanya sekedar tercapai atau mungkinbahkan tidak tercapai. Kesemuanya itu diperlukan sebagai bahan dan dasar untuk mengambil keputusan dimasa depan.

\section{PENUTUP}

Program kepala sekolah dalam meningkatkan kompetensi guru pada SMA Negeri 1 Peukan Bada Kabupaten Aceh Besar disusun pada setiap awal semester atau awal tahun pelajaran oleh tim pengembang sekolah yang meliputi program tahunan dan program semester dan sudah terdokumentasi dengan baik dan rapi di ruang tata usaha. 
FITRAH Jurnal Kajian Ilmu-ilmu Keislaman

Vol. 04 No. 1 Juni 2018

Pelaksanaan program dalam meningkatkan kompetensi guru pada SMA Negeri 1 Peukan Bada Kabupaten Aceh Besar diawali dengan menyampaikan arahan pada setiap awal semester. Dalam melaksanakan manajemen sekolah strategi kepala sekolah/sekolah menerapkan dengan prinsip kekeluargaan, namun tetap mengacu adanya penghargaan bagi yang selalu meningkatkan kompetensinya.

Evaluasi kepala sekolah dalam meningkatkan kompetensi guru dilaksanakan pada setiap akhir semester melalui penilain kinerja guru yang dijabarkan dalam SKP. Hasil evaluasi dijadikan sebagai tindak lanjut dalam menentukan program kanjutan dan disampaikan kepda guru secara individual dan sacara umum melalui rapat.

Hambatan-hambatan yang dihadapi kepala sekolah antara lain masih rendahnya kualitas sumberdaya manusia (SDM), Kurangnya kesadaran guru dalam menegakkan kedisiplinan dan rendahnya kesadaran siswa kedisiplinan. 


\section{DAFTAR PUSTAKAAN}

Aidin Adlan, 2000, Hubungan Sikap Guru Terhadap Matematika dan Motivasi Berprestasi dengan Kinerja, Matahari No.1, Jakarta.

Idris, S \& Tabrani, Z. A. (2017). Realitas Konsep Pendidikan Humanisme dalam Konteks Pendidikan Islam. Jurnal Edukasi: Jurnal Bimbingan Konseling, 3(1), 96-113.

Kunandar, 2008, Guru Profesional Implementasi Kurikulum tingkat satuan pendidikan dan Sukses dalam Sertifikasi Guru, Jakarta: Raja Grafindo Persada.

Masitoh dan Laksmi Dewi, 2009, Strategi Pembelajaran, Jakarta: Direktorat Jendral Pendidikan Islam Departemen Agama RI.

Nufiar, N., \& Idris, S. (2016). Teacher Competence Test of Islamic Primary

Teachers Education in State Islamic Primary Schools (MIN) of Pidie

Regency. Jurnal Ilmiah Peuradeun, 4(3), 309-320.

Sarimaya,farida, 2008, Serifikasi Guru .Apa,Mengapa,Dan Bagaimana, Bandung: Yrama Widya.

Suharsimi Arikunto, 2003, Manajemen Pengajaran Secara Manusiawi, Jakarta : Rineka Cipta.

Suzanne, R., \& Nathalie, L. (2016). Multiculturalism as an Alternative A Cultural Orientation to Education in the Aspect of Culture as the Axiological Focus. Jurnal Ilmiah Peuradeun, 4(3), 383-394.

Syah Muhibbin, 2013, Psikologi Pendidikan dengan Pendekatan Baru, Remaja Rosdakarya, Bandung.

Tabrani. ZA \& Masbur, M. (2016). Islamic Perspectives on the Existence of Soul and Its Influence in Human Learning (A Philosophical Analysis of the Classical and Modern Learning Theories). Jurnal Edukasi: Jurnal Bimbingan Konseling, 1(2), 99-112.

Tabrani. ZA. (2014). Islamic Studies dalam Pendekatan Multidisipliner (Suatu Kajian Gradual Menuju Paradigma Global). Jurnal Ilmiah Peuradeun, 2(2), 211234.

Tabrani. ZA. (2014). Isu-Isu Kritis dalam Pendidikan Islam. Jurnal Ilmiah Islam Futura, $13(2), 250-270$ 
FITRAH Jurnal Kajian Ilmu-ilmu Keislaman

Vol. 04 No. 1 Juni 2018

Tabrani. ZA. (2016). Perubahan Ideologi Keislaman Turki (Analisis Geo-Kultur Islam dan Politik Pada Kerajaan Turki Usmani). Jurnal Edukasi: Jurnal Bimbingan Konseling, 2(2), 130-146.

Trianto, 2011, Desain Pengembangan Pembelajaran Tematik ( Bagi Anak Usia Dini, TK IRA \& Anak Usia Kelas Awal SD / MI, Jakarta: Prenada Media Group.

Usman, Uzer Moh. 2013, Menjadi Guru Profesional. Bandung: Remaja Rosda Karya.

Walidin, W. (2016). Informal Education as A Projected Improvement of the Professional Skills of Employees of Organizations. Jurnal Ilmiah Peuradeun, 4(3), 281-294. 